\title{
Teratogenic effects of cypermethrin and carbaryl on swiss albino mice (Mus musculus)
}

\section{Muhammad Saqib Sajid, Razia Iqbal, Mubashar Hussain*, Muhammad} Faheem Malik and Suleman Hussain Shah

Department of Zoology, University of Gujrat, Punjab-Pakistan

*Corresponding author's email:dr.mubashar@uog.edu.pk

Citation

Muhammad Saqib Sajid, Razia Iqbal, Mubashar Hussain, Muhammad Faheem Malik and Suleman Hussain Shah. Teratogenic effects of cypermethrin and carbaryl on swiss albino mice (Mus musculus). Pure and Applied Biology. Vol. 8, Issue 2, pp1510-1522. http://dx.doi.org/10.19045/bspab.2019.80092

Received: 28/01/2019

Revised: 03/05/2019

Accepted: $15 / 05 / 2019$

Online First: 18/05/2019

\section{Abstract}

Toxic effects of cypermethrin and carbaryl were determined by studying histopathological changes in the liver and kidney of developing fetus of Swiss albino mice during 2018. The mice were kept under controlled conditions of temperature $\left(25^{\circ} \mathrm{C}\right)$, relative humidity $(40-50 \%)$ and photoperiod $12 \mathrm{hrs}$ : $12 \mathrm{hrs}$. The pregnant female mice were exposed to two dose groups of $5 \mathrm{mg} / \mathrm{g}$ body weight (b.w.) and $7.5 \mathrm{mg} / \mathrm{g}$ of b.w. The doses were administrated orally daily at morning for eighteen days during gestation. Cesarean sections were performed on eighteenth day and fetuses were recovered for morphological and morphometric analysis which revealed normal development of external organs in all treatment groups except in the group where $7.5 \mathrm{mg} / \mathrm{g}$ of b.w. of cypermethrin was applied. High dose group of cypermethrin $(7.5 \mathrm{mg} / \mathrm{g}$ of b.w.) showed significant variations in the reduction of body weight $(311.47 \mathrm{mg})$, crown rump $(\mathrm{CR})$ length $(11.23 \mathrm{~mm})$ and tail length $(7.25$ $\mathrm{mm}$ ) with arrested growth as compared to other groups. Results showed sinusoid enlargement, congestion of central vein, dilation of tubular portion, necrosis, hemorrhages along with irregular hepatocytes in kidney and liver in all treatment groups. Higher dose of cypermethrin caused slight teratological effects on fetus. Physical and morphological abnormality was not observed in all groups including control. The present study concludes that the cypermethrin produces teratological effects in addition to reduction in the growth of developing fetus mice, thus, may be explored further for hazardous effects.

Keywords: Histopathology; Kidney; Liver; Pesticides; Teratogenic

\section{Introduction}

Teratogenic substances have ability to produce abnormal development during gestation resulting in structural and functional defects as compared to normal development [1]. Pesticide use in the agriculture and public health pest control programs kills targeted as well as non- targeted species including human beings [2]. Pesticides are reported as one of the main causes for the fetal anomalies and CNS defects [3]. Pesticides accumulation in food chains affects physiological, behavioral and hormonal functions of species ultimately leading to the decline of biodiversity [4]. Cypermethrin belongs to the Pyrethroid 
family of insecticides and used extensively to manage parasites and pests of food and fiber crops [5]. Twitching, salivation and startle due to cypermethrin toxicity as it affects the sodium channel of both types of nervous system [6]. Cypermethrin toxicity showed increase in the level of Nitric oxide synthase (NOs) and Malondialdehyde (MDA) by blocking antioxidant enzymes [7]. Cypermethrin imparts injurious effects on the testes including defective seminiferous tubules, germ cell, decreased sperm production, Follicle-Stimulating Hormone (FSH) and increased testosterone levels [8]. In mice, increased capacity of glutamate dehydrogenase, lactate dehydrogenase and glucose-6-phosphate and decreased activity of succinate dehydrogenase in muscles and kidneys were observed due to cypermethrin and sodium fluoride [9]. Salivation, tremors in muscular region along with reproductive defects including embryo mortality and uterine structure defects were observed due to cypermethrin application in female rabbits [10]. Cypermethrin applications caused oligospermia, morphological defect in sperm and birth defect in animal and plant species [11].

Many researchers used a number of animals to check the toxicity of the pesticides. These pesticides were transferred to organism body by different means especially through oral route, inhalation or through skin contact. As a result, a number of complications arises like vomiting, headache, dizziness, skin problems and nose abnormality in fetus [12].

Application of carbaryl to zebra fish caused delayed development and hatching [13]. Low concentration of carbaryl did not produce any variation in weight of testes of fish but it produced histological changes in testes. Blood clotting in the testes due to carbaryl and chlorpyriphos application damaged the tissues [14]. Enlarged hepatocytes, fat deposition, inflammation, constriction, dilated vessels in hepatic portal area and hepatitis were observed in liver of albino rats due to carbaryl administration [15]. In fish, carbaryl and carbofuran application caused imbalance and restlessness, breathing difficulty along with diminished energy level leading to the death of the fish [16]. Accumulation of cellular mass, disorganization of seminiferous tubules, loosely attached germ cells along with decreased spermatogenesis and sperms were observed due to carbaryl application [17]. In white rats, carbaryl imparted histopathological changes in vital organs i.e. liver, heart, kidney and brain [18].

The present study was undertaken to determine the teratogenic and toxic effects of cypermethrin and carbaryl on the developing fetus of mice.

\section{Materials and methods Experimental animals}

Thirty seven albino white mice including 12 males and 25 females of the same age group were obtained from University of Veterinary and Animal Sciences (UVAS), Lahore. These mice were kept in steel cages and provided with the photoperiod of light to darkness ratio (12 hrs: $12 \mathrm{hrs).} \mathrm{The} \mathrm{mice} \mathrm{were} \mathrm{exposed} \mathrm{to}$ $25{ }^{\circ} \mathrm{C}$ temperature and $45 \pm 5 \%$ relative humidity. After the confirmation of estrus cycle by the vaginal smear method and physical signs, one male and two estrus females were isolated for mating overnight. After confirmation from vaginal plug, it was marked as zero (0) day of gestation and females were isolated after mating for the exposure to different treatment groups.

\section{Treatment groups}

Commercial grade carbaryl and cypermethrin were administered to each group comprises of five pregnant females. Two dose groups 5 $\mathrm{mg} / \mathrm{g}$ and $7.5 \mathrm{mg} / \mathrm{g}$ of body weight for each insecticide in addition to control group were designed. The doses were administrated for eighteen days during gestation period. The pesticide doses were diluted in vegetable oil and administered orally through plastic 
syringe that was covered with rubber tube. On the eighteenth day, the mice were dissected for morphometric and histopathological analysis.

Fetuses, organ extraction and histological analysis

The female mice were weighed and anesthetized with ether for cesarean section. The uterus was removed and fetuses were recovered and counted [19]. The kidney and liver were extracted from mother mice for histopathological analysis. The removed organs were dipped into bovine fixative for eight hours and fetuses were preserved in 70 $\%$ alcohol. The dissected fetuses were subjected to dissecting microscope with camera for morphometric and morphological analysis. Fetuses were put under binocular dissecting microscope and photographed by digital camera (Canon DMC-TZ15) with focal length of $4.7 \mathrm{~mm}$ and dimensions of $3445 \times 2592$. The extracted organs from the adult mice were subjected to histological analysis by following the method of [20].

\section{Statistical analysis}

ANOVA and Post Hoc test were applied to analyze the data and compare the significance of means by SPSS.

\section{Results and discussion}

Morphological, morphometric and

histopathological observations

\section{Control group}

Forty implantations were recovered from the control group. Normal development of organs including head tail and limbs etc. were observed. Head showed normal development and texture along with jaws. Skin was thick and wrinkled covering the abdominal organs. Abdominal area was protruded out and thoracic area was flattened. Well-developed sensory organs were observed. The eyes were elliptical with upper and lower eyelids having lens in the central area exhibit normal development. Normal developed external pinna with prominent meatus of ears was observed. Two closely lied nostrils at the proximal portion of the nose and presence of vibrissae on the snout were noted (Figure 1). The morphometric parameters that were observed were normal. The body weight, crown rump (CR) length and head circumference means of fetuses were $555.7275 \mathrm{mg}, 16.2803 \mathrm{~mm}$ and $27.422 \mathrm{~mm}^{2}$ respectively (Table 1). The forelimb and hind limb sizes means were $6.3188 \mathrm{~mm}$ and $6.9678 \mathrm{~mm}$ respectively. The eye circumference mean of the fetuses was $6.5915 \mathrm{~mm}^{2}$ and the tail length of fetuses was $11.1040 \mathrm{~mm}$. There were no reabsorbed and malformed fetuses seen in this group (Table 2).

The histopathological results of liver of control group clearly demonstrated normal appearance of hepatocytes. No congestion, hemorrhage, necrosis or dilation was observed. Sinusoidal spaces and central vein were also normal. Similarly, the cross section of kidney of control group appeared normal. Nothing like necrosis, dilation of tubular part was observed. The medullary portion and tubular portion were normal (Figure $7 \& 12$ ).

Cypermethrin (high dose)

Thirty five implantations were recovered from high dose group of cypermethrin received dose of $7.5 \mathrm{mg} / \mathrm{g}$ body weight. All body parts including sense organs were normal. Head and jaws were normal in their appearance. Eyes were well developed with lenses and eyelids. Meatus and external pinnae of the ear were also normally developed. Wrinkled unpigmented skin with protruded abdominal area and flattened thoracic area was observed. Vibrissae on snout and appearance of nostril at proximal portion of the nose were observed. Arrested growth of the fetuses was observed in this group (Figure 2).

The head circumference, body weight and CR length means of fetuses were 26.1100 $\mathrm{mm}^{2}, \quad 311.4771 \mathrm{mg}$ and $11.2377 \mathrm{~mm}$ respectively (Table 1). These parameters and arrested growth clearly deviate from the 
control group. Reduction in number of implantations, body weight, CR length, tail, and arrested growth showed the toxicity of the cypermethrin (Figure 3). The forelimb and hind limb sizes were $5.6994 \mathrm{~mm}, 6.3203$ $\mathrm{mm}$ respectively. The eye circumference mean of the fetuses was $5.7800 \mathrm{~mm}^{2}$ (Table 2).

The histopathological analysis of liver of high dose group of cypermethrin showed irregular, degenerated hepatocytes. Hemorrhage, necrosis, congestion of central vein and sinusoidal enlargement were observed in this group. The kidney cross section showed enlargement of tubular portion and necrosis (Figure $8 \& 13$ ).

\section{Cypermethrin (low dose)}

Thirty seven fetuses were recovered from the low dose group of cypermethrin received dose of $5 \mathrm{mg} / \mathrm{g}$ b.w. of cypermethrin. Normal development of organs including sense organs and limbs were seen. No remarkable differences were seen from control group except tail length. Head and jaws were normal in their appearance. Wrinkled unpigmented skin with protruded abdominal area and flattened thoracic area were observed. Vibrissae on snout and appearance of nostril at proximal portion of the nose were observed. Meatus and external pinnae of the ear were also normal and well developed. Eyes were well developed with lenses and eyelids (Figure 4).

These fetuses have head and eye circumferences means of $6.6284 \mathrm{~mm}^{2}$ and $27.4470 \mathrm{~mm}^{2}$ respectively. The body weight with CR length mean were $459.9270 \mathrm{mg}$ and $16.3003 \mathrm{~mm}$ respectively. The tail length, forelimb size and hind limb means of the fetuses were $8.9630 \mathrm{~mm}, 6.2700 \mathrm{~mm}$ and $7.1468 \mathrm{~mm}$ respectively (Table $1 \& 2$ ).

The liver cross section of low dose group of cypermethrin showed irregular hepatocytes, sinusoidal enlargement and congested central vein. The kidney cross section showed normal tubular area but necrosis (Figure $9 \&$ 14).

\section{Carbaryl (high dose)}

Thirty seven implantations were recovered from high dose group of carbaryl received dose of $7.5 \mathrm{mg} / \mathrm{g}$ body weight. There was no distinct variation in the body parts of the fetuses. All body parts including sense organs were normal in their appearance. Wrinkled unpigmented skin with protruded abdominal area and flattened thoracic area were observed. Head and jaws were normal in their appearance. Eyes were well developed with lenses and eyelids. Meatus and external pinnae of the ear were also normal and well developed. Vibrissae on snout and appearance of nostril at proximal portion of the nose were observed (Figure 5).

These fetuses have average body weight of $513.3297 \mathrm{mg}$ with CR length of $15.5295 \mathrm{~mm}$. The mean tail length of the fetuses was $11.3824 \mathrm{~mm}$. The average eye circumference mean of $6.3616 \mathrm{~mm}^{2}$ and head circumference mean of $27.5673 \mathrm{~mm}^{2}$ were observed. The average forelimb size mean was $6.3561 \mathrm{~mm}$ and hind limb mean was $7.4316 \mathrm{~mm}$ (Table 1 $\& 2)$.

The cross section of liver of high dose group of carbaryl showed irregular, elliptical hepatocytes and necrosis. The cross section of kidney showed dilation of the tubular portion (Figure $10 \& 15$ ).

\section{Carbaryl (low dose)}

Thirty eight fetuses were recovered from low dose group of carbaryl received dose of $5 \mathrm{mg} / \mathrm{g}$ of b.w. There was no prominent variation seen in the fetuses of this group. All body parts were grown normally. Wrinkled unpigmented skin with protruded abdominal area and flattened thoracic area were observed. Head and jaws were normal in their appearance. Eyes were well developed with lenses and eyelids. Meatus and external pinnae of the ear were also normal and well developed. Vibrissae on snout and 
appearance of nostril at proximal portion of the nose were observed (Figure 6).

The fetuses have body weight and CR length means of $511.9237 \mathrm{mg}$ and $15.5295 \mathrm{~mm}$ respectively (Table 1). The head circumference and eye circumference means were $26.8008 \mathrm{~mm}^{2}$ and $6.4108 \mathrm{~mm}^{2}$ respectively. The tail length, forelimb and hind limb size means were $11.4292 \mathrm{~mm}$, $6.3561 \mathrm{~mm}$ and $7.3992 \mathrm{~mm}$ respectively (Table 2).

The cross section of the liver of low dose group of the carbaryl showed normal hepatocytes with dilation of sinusoid and congestion and dilated central vein. The cross section of the kidney showed congestion in glomerular portion (Figure $11 \& 16$ ).

Carbaryl and cypermethrin were used to investigate their toxic effect on the developing fetus of mice as well as to check the toxicity effect on liver and kidney. The findings of our study revealed that carbaryl did not produce major changes or developmental anomalies. These finding concur with the finding of [21-23] as these described that carbaryl did not cause major variation in viability and fertility and with $[24,25]$ as these described no teratogenic effect as well as reproductive effect due to carbaryl in mice and rhesus monkeys. However, our findings did not concur with the finding of [26] who reported carbaryl produced teratogenic effect at high dosage and with [27] who reported carbaryl caused teratogenic effect in guinea pigs. Carbaryl toxicity is dose dependent as some researchers [28] reported higher doses of carbaryl were toxic to fetuses in mice and low dose did not produce any effect. Similarly, [29] who also reported carbaryl toxicity was dose dependent in rats. Direct Embryo death through pesticides did not occur but it causes reduction in embryo size [13].

Arrested growth, reduction in the length of tail and crown and reduction in body weight of fetuses were seen in the high dose group of cypermethrin, similarly reduction in tail length were also observed in low dose group of cypermethrin. These findings were due to high dose of cypermethrin is alike with [30] who described body weight reduction of the chick embryo and [31] who reported the body weight and crown rump length reduction in Japanese quail [32-34] and reported reduction in body weight and $\mathrm{CR}$ length reduction delay in opening and development of Pinnae of mice. The present study was contrary to other researchers like [35-37]. These researchers reported severe fetal anomalies. Our findings due to toxicity of cypermethrin and carbaryl agrees with [38] which stated size and body weight reduction in the litter for three generations. This study was also concurring with [13] who reported mortality and delayed hatching of embryo of zebrafish. A number of physical signs like temporary paralysis in the limb portion were observed in adult mice due to pesticide treatment. Food intake during treatment was poor and these findings concur with the finding of $[39,40]$.

Liver and kidney of adult pregnant female mice were subjected to pesticide to check their toxic effect. The high and low doses of cypermethrin and carbaryl were given to pregnant mice for eighteen days. After that the liver and kidney were extracted for histopathological analysis. In kidney and liver histopathology control and treatment groups were compared to check the toxicity of both pesticides. The results clearly demonstrated that control group showed normal texture of hepatocytes, no congestion, necrosis and dilation were seen in liver, and similarly normal appearance without dilated tubular portion of kidney was seen in control group. But the treatment groups clearly showed the toxic effect of pesticides as irregular hepatocytes, congestion and necrosis were seen in the liver, similarly dilation of tubular portion congestion and necrosis of kidney were seen. 
A number of researchers used different organisms to investigate the deleterious and damaging effect of pesticides as these pesticides were applied by different means including dermal exposure as well as oral administration. These pesticides showed complications in the organism as irritation of nose skin and eyes, developmental anomalies as well as headache dizziness and vomiting [12].

The present study showed that cypermethrin and carbaryl administration through oral root imparted injurious effect on the liver and kidneys of the treated mother mice. The hepatocytes were irregular in shape, hepatocyte degeneration, sinusoid enlargement, necrosis and hemorrhage in liver. Similarly, necrosis, congestion and dilation of tubular portion in the kidneys was reported in treated groups after eighteen days treatment. The irregular shapes of the hepatocytes showed the over activity of liver due to cypermethrin and carbaryl metabolism as these enter into liver [15]. These studies coincide with the study of $[15,42]$. They reported over activity and degeneration, shape changes in the liver cell due to carbaryl administration and cypermethrin. Irregular shapes of hepatocytes, necrosis and hemorrhage sinusoidal expansion with pycnotic nuclei, structural changes in hepatic lamina in the liver cell, glomerular constriction in the kidney with renal tubules cell degeneration and necrosis of glomeruli and tubular parts. The present study clearly indicated that lower dose and high dose imparted injurious defects in liver and kidney. This study also clearly showed that oral administration even at low dose was enough to cause injurious and lethal damages to vital organs like liver and kidney.

Table 1. Morphometric analysis of 18-day-old mice fetuses recovered from pregnant mice, administrated orally with different concentrations of cypermethrin and carbaryl during gestation

\begin{tabular}{|c|c|c|c|c|}
\hline $\begin{array}{c}\text { Dose } \\
\text { Groups } \Delta\end{array}$ & $\begin{array}{c}\text { Number of } \\
\text { Implantations } \\
(\mathbf{N})\end{array}$ & $\begin{array}{c}\text { Body } \\
\text { Weight } \\
(\mathbf{m g} \pm \text { S.E. })\end{array}$ & $\begin{array}{c}\text { CR Length } \\
(\mathbf{m m} \pm \text { S.E. })\end{array}$ & $\begin{array}{c}\text { Head } \\
\text { Circumference } \\
\left(\mathbf{m m}^{2} \pm \text { S.E. }\right)\end{array}$ \\
\hline Control & 40 & $555.7275 \pm 3.38408^{\mathrm{d}}$ & $16.2803 \pm .56506^{\mathrm{b}}$ & $27.422 \pm .34584^{\mathrm{a}}$ \\
\hline $\begin{array}{c}\text { Cypermethrin } \\
(7.5 \mathrm{mg} / \mathrm{g} \text { b.w. })\end{array}$ & 35 & $311.4771 \pm 9.71873^{\mathrm{a}}$ & $11.2377 \pm .26861^{\mathrm{a}}$ & $26.1100 \pm .23997^{\mathrm{b}}$ \\
\hline $\begin{array}{c}\text { Cypermethrin } \\
\text { (5m/g b.w.) }\end{array}$ & 37 & $459.9270 \pm 5.83868^{\mathrm{b}}$ & $16.3003 \pm .36330^{\mathrm{b}}$ & $27.4470 \pm .30374^{\mathrm{a}}$ \\
\hline $\begin{array}{c}\text { Carbaryl } \\
\text { (7.5mg/g b.w.) }\end{array}$ & 37 & $513.3297 \pm 5.36600^{\mathrm{c}}$ & $15.5295 \pm .30946^{\mathrm{b}}$ & $27.5673 \pm .23635^{\mathrm{a}}$ \\
\hline $\begin{array}{c}\text { Carbaryl } \\
\text { (5m/g b.w.) }\end{array}$ & 38 & $511.9237 \pm 7.01269^{\mathrm{c}}$ & $15.7468 \pm .30660^{\mathrm{b}}$ & $26.8008 \pm .69098^{\mathrm{a}}$ \\
\hline
\end{tabular}

The similar superscript indicate significance $<0.05$ and different superscript shows non-significance $>0.05$ among column 
Table 2. Morphometric analysis of 18-day-old mice fetuses recovered from pregnant mice, administrated orally with different concentrations of cypermethrin and carbaryl during gestation

\begin{tabular}{|c|c|c|c|c|}
\hline $\begin{array}{c}\text { Dose } \\
\text { Groups }\end{array}$ & $\begin{array}{c}\text { Eye } \\
\text { Circumference } \\
\left(\mathbf{m m}^{2} \pm \text { S.E. }\right)\end{array}$ & $\begin{array}{c}\text { Forelimb } \\
\text { Size } \\
(\mathbf{m m} \pm \text { S.E. })\end{array}$ & $\begin{array}{c}\text { Hindlimb } \\
\text { Size } \\
(\mathbf{m m} \pm \text { S.E. })\end{array}$ & $\begin{array}{c}\text { Tail } \\
\text { Length } \\
(\mathbf{m m} \pm \text { S.E. })\end{array}$ \\
\hline Control & $6.5915 \pm .15717^{\mathrm{a}}$ & $6.3188 \pm .20706^{\mathrm{a}}$ & $6.9678 \pm .20215^{\mathrm{a}}$ & $11.1040 \pm .24793^{\mathrm{a}}$ \\
\hline $\begin{array}{c}\text { Cypermethrin } \\
(7.5 \mathrm{mg} / \mathrm{g} \text { b.w. })\end{array}$ & $5.7800 \pm .13466^{\mathrm{b}}$ & $5.6994 \pm .16822^{\mathrm{a}}$ & $6.3203 \pm .16285^{\mathrm{a}}$ & $7.2597 \pm .18939^{\mathrm{b}}$ \\
\hline $\begin{array}{c}\text { Cypermethrin } \\
(5 \mathrm{~m} / \mathrm{g} \text { b.w. })\end{array}$ & $6.6284 \pm .16012^{\mathrm{b}}$ & $6.2700 \pm .14081^{\mathrm{a}}$ & $7.1468 \pm .13497^{\mathrm{a}}$ & $8.9630 \pm .20444^{\mathrm{c}}$ \\
\hline $\begin{array}{c}\text { Carbaryl } \\
(7.5 \mathrm{mg} / \mathrm{g} \text { b.w. })\end{array}$ & $6.3616 \pm .16725^{\mathrm{b}}$ & $6.3561 \pm .16594^{\mathrm{a}}$ & $7.4316 \pm .17364^{\mathrm{a}}$ & $11.3824 \pm .23389^{\mathrm{a}}$ \\
\hline $\begin{array}{c}\text { Carbaryl } \\
\text { (5m/g b.w. })\end{array}$ & $6.4108 \pm .16703^{\mathrm{b}}$ & $6.3561 \pm .16472^{\mathrm{a}}$ & $7.3992 \pm .16746^{\mathrm{a}}$ & $11.4292 \pm .24630^{\mathrm{a}}$ \\
\hline
\end{tabular}

The similar superscript indicate significance $<0.05$ and different superscript shows non-significance $>0.05$ among column

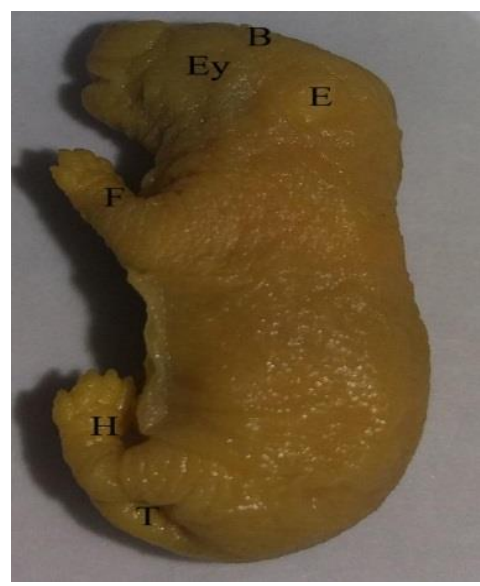

Figure 1. Eighteen Days Macrophotograph of control fetus showing normal development of Brain $(B)$, Eye (Ey), Ears(E), Forelimb(F) Hindlimb(H), and Tail (T)
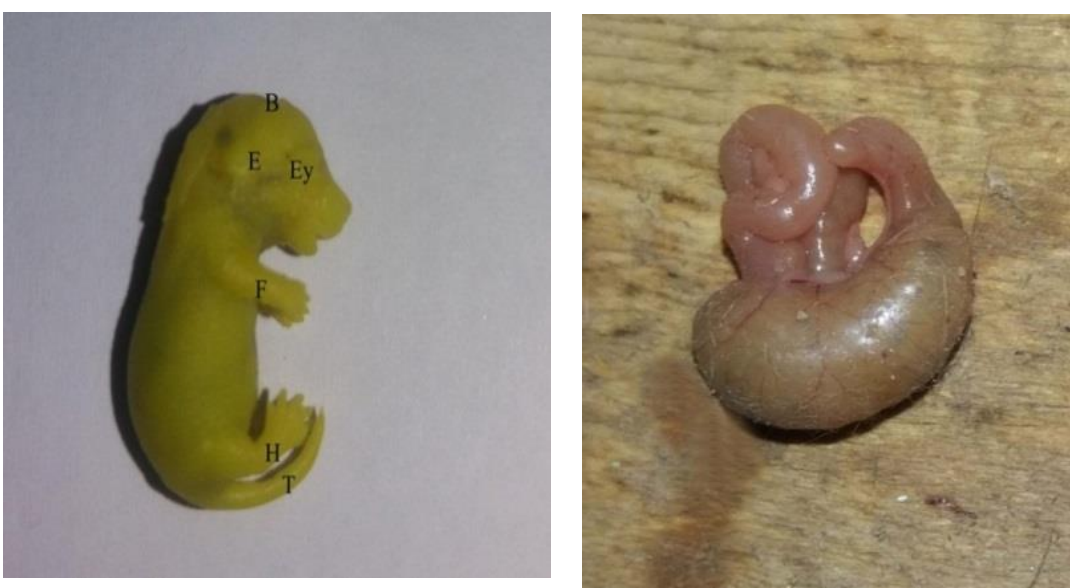

Figure 2. Eighteen Days

Macrophotograph of Fetus of high dose group of cypermethrin ( $7.5 \mathrm{mg} / \mathrm{g}$ body weight) showing normal development of body organs like Brain(B), Eye (Ey), Ears (E), Forelimb (F), Hindlimb (H) and Tail (T)
Figure 3. Arrested growth of fetus was observed in the mother mice of high dose mg/g body weight) group of cypermethrin $(7.5$ 


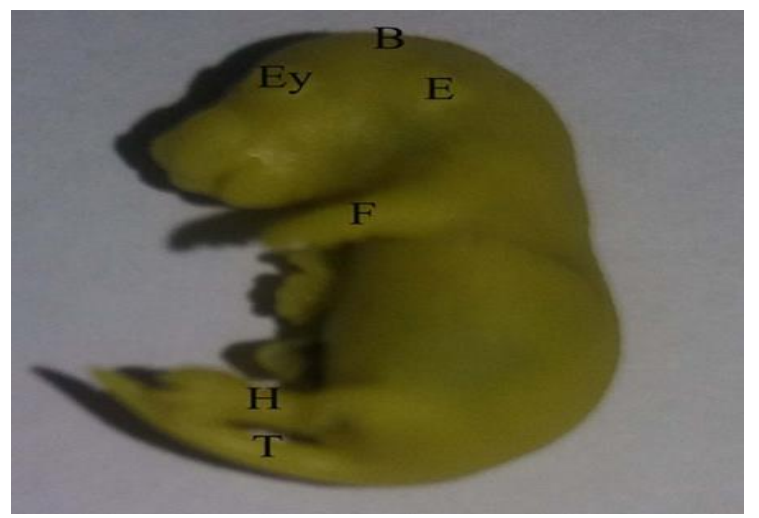

Figure 4. Eighteen Days Macrophotograph of Fetus of low dose group of cypermethrin $(5 \mathrm{mg} / \mathrm{g}$ body weight) showing normal development of body organs like Forelimb (F), Hindlimb $(\mathbf{H})$, Tail (T), Eye (Ey), Ears(E), and Brain(B)

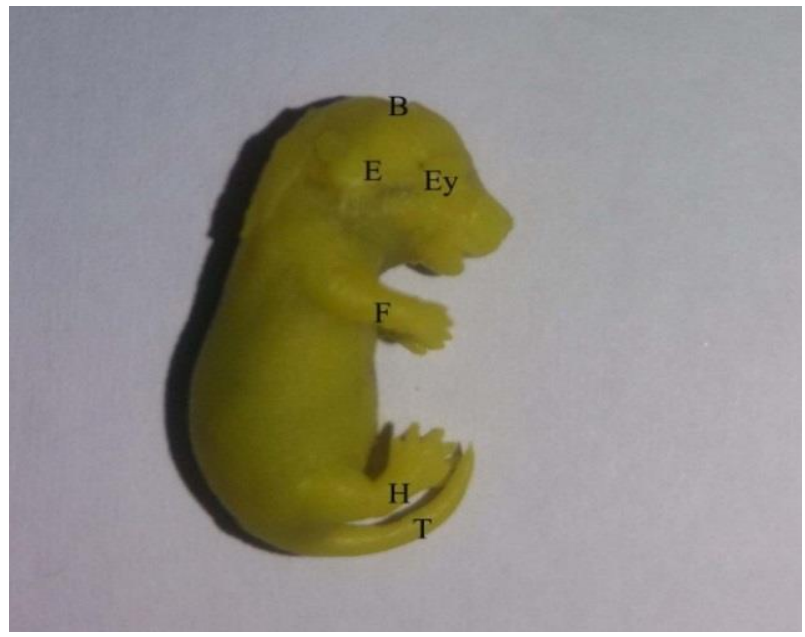

Figure 6. Eighteen Days Macrophotograph of Fetus of low dose group of carbaryl $(5 \mathrm{mg} / \mathrm{g}$ body weight) showing normal development of body like Forelimb(F), Hindlimb (H), Tail (T), $\operatorname{Eye}(\operatorname{Ey}), \operatorname{Ears}(E)$, and Brain(B)

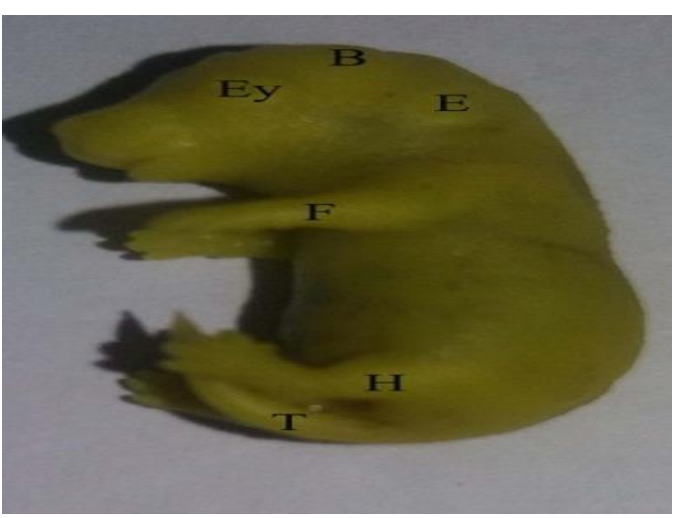

Figure 5. Eighteen Days Macrophotograph of Fetus of high dose group of carbaryl $(7.5 \mathrm{mg} / \mathrm{g}$ body weight) showing normal development of Body. It Showed Normal Development of Forelimb(F), Hindlimb (H), Tail (T), Eye(Ey), Ears(E), and Brain $(B)$

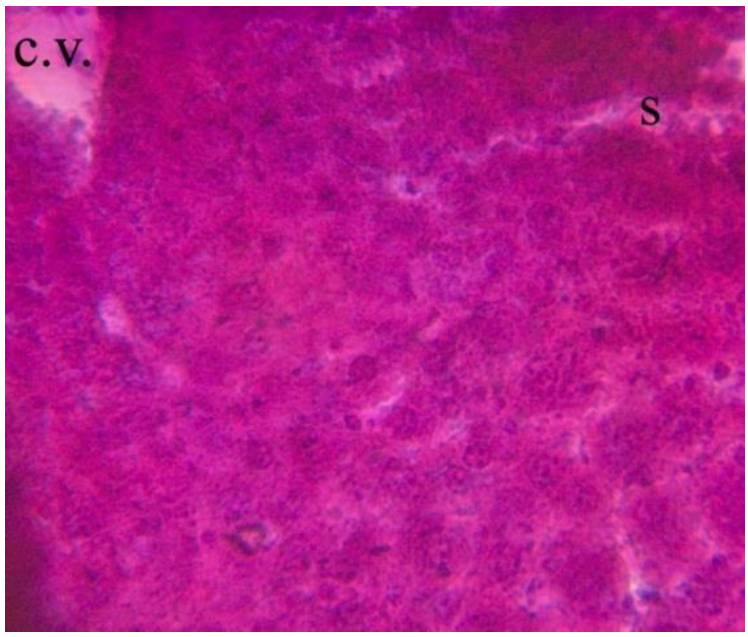

Figure 7. Cross Section of Liver of Control Group showing normal hepatocytes with normal sinusoidal space $(S)$ and central vein (C.V). (100x Magnification Power under Light Microscope) 


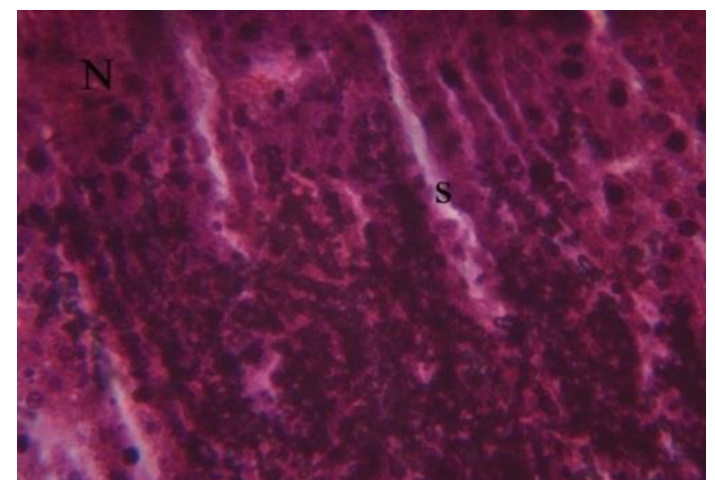

Figure 8. Liver cross section of high dose group of cypermethrin $(7.5 \mathrm{mg} / \mathrm{g}$ body weight) showing irregular, degenerated hepatocytes. Necrosis $(\mathbf{N})$ sinusoidal enlargement $(\mathbf{S})$ and hemorrhage can be seen due to cypermethrin toxicity. (100x Magnification Power under light Microscope)

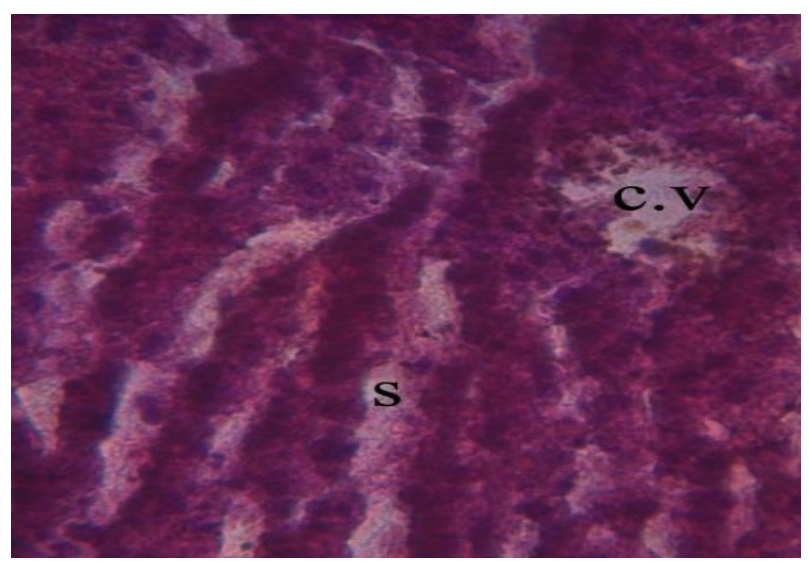

Figure 9. Liver cross section of low dose group of cypermethrin ( $5 \mathrm{mg} / \mathrm{g}$ body weight) showed irregular hepatocytes with enlarged sinusoidal space (S) and Congested Central Vein (C.V) (100x Magnification Power under Light Microscope)

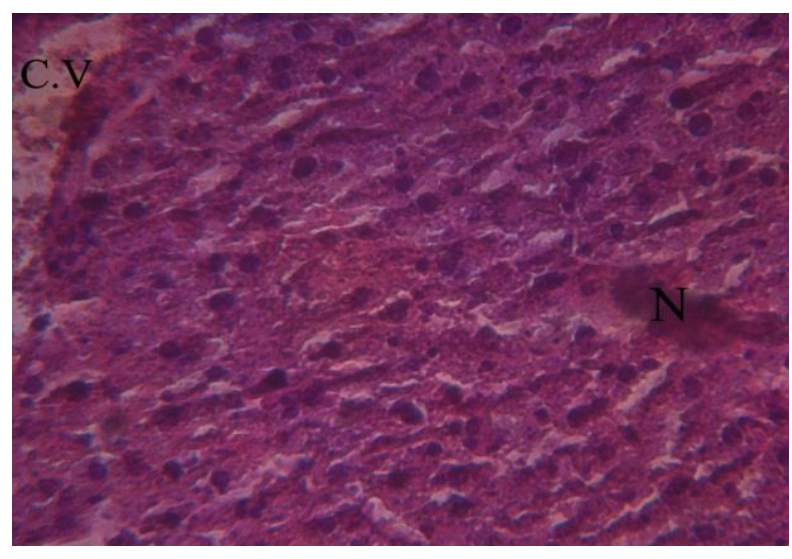

Figure 10. Liver cross section of high dose group of carbaryl ( $7.5 \mathrm{mg} / \mathrm{g}$ b.w.) showing irregular, elliptical hepatocytes. The congested central vein (C.V.) and necrosis $(\mathrm{N})$ also observed. The Irregular Shapes of the Hepatocytes Show the Over Activity of Liver Due To Carbaryl Metabolism at 100x Magnification Power under Light Microscope 


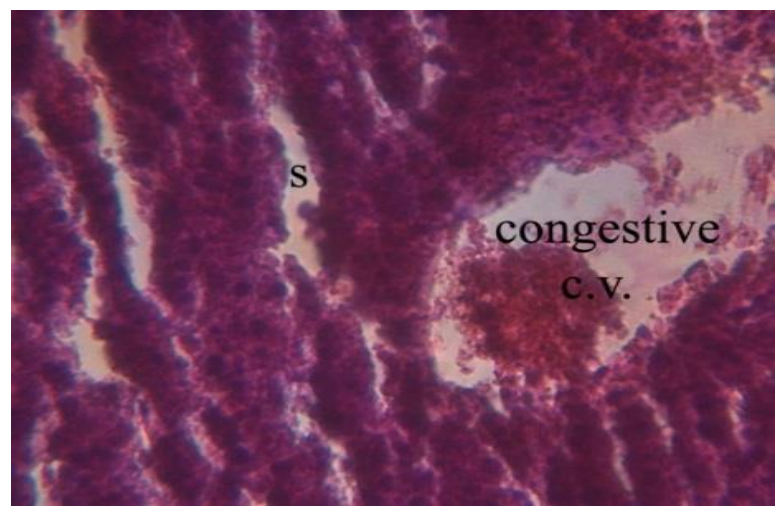

Figure 11. Liver cross section of low dose group of carbaryl (5 mg/g b.w.) showing normal appearance of hepatocytes with congested central vein and sinusoidal dilation (100x Magnification Power under Light Microscope)

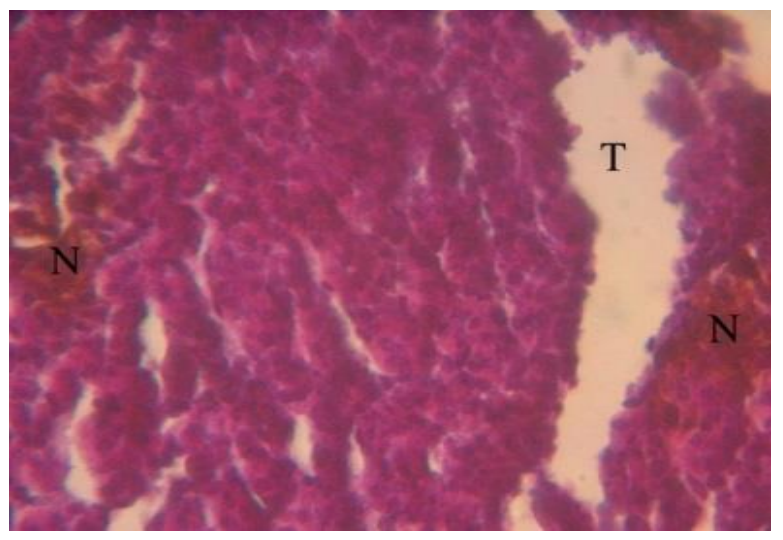

Figure 13. Kidney cross section of high dose group of cypermethrin $(7.5 \mathrm{mg} / \mathrm{g}$ b.w.) showing enlarged tubular area $(T)$ and necrosis $(N)$ at 100x Magnification Power under Light Microscope

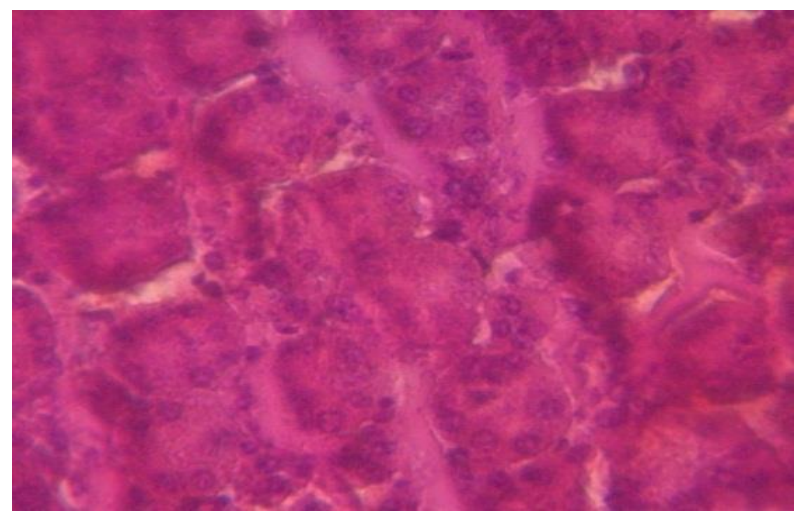

Figure 12. Kidney cross section of control group showing normal appearance of medullary portion with normal tubular area of the kidney at 100x Magnification Power under Light Microscope

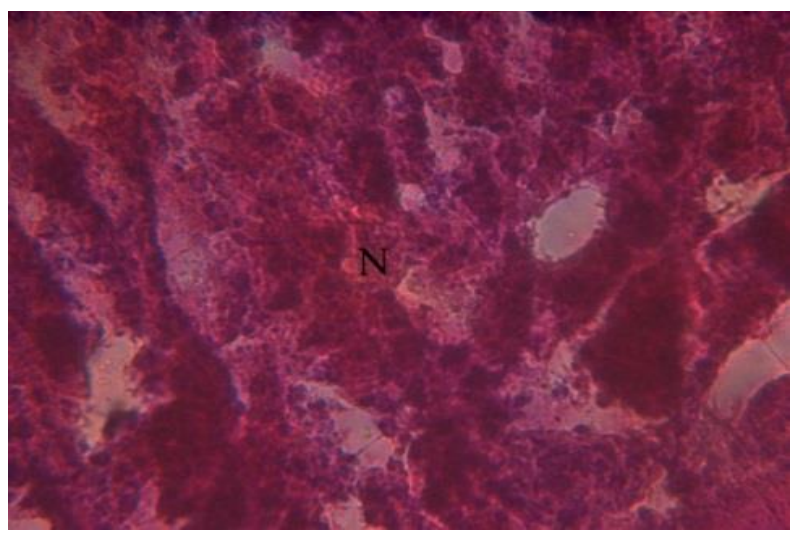

Figure 14. Kidney cross section of low dose group of cypermethrin $(5 \mathrm{mg} / \mathrm{g}$. b.w.) showing necrosis $(\mathrm{N})$. Normal Tubular area at 100x Magnification Power under Light Microscope 


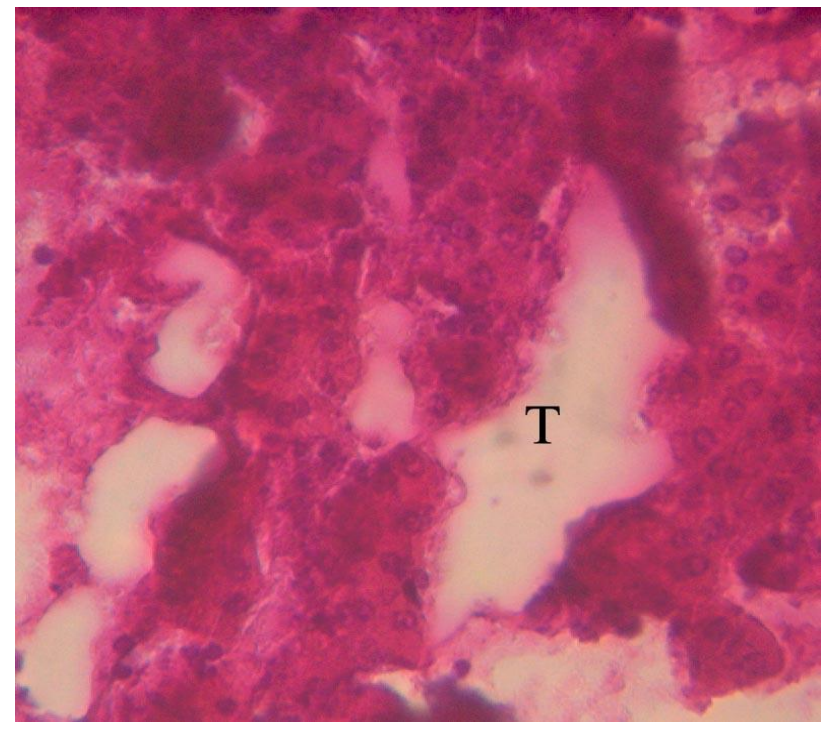

Figure 15. Kidney cross section of high dose group of carbaryl $(7.5 \mathrm{mg} / \mathrm{g} \mathrm{b.w.)}$ showing dilated tubular area (T). Necrosis and hemorrhage was not observed at 100x Magnification Power under Light Microscope

\section{Conclusion}

This study revealed that the doses of carbaryl (high and low) and low dose of cypermethrin did not produce any major teratological effect on the developing fetus mice while the high dose of cypermethrin caused slight teratological effect as it caused reduction in fetus body weight and reduction in the length of CR and tail. The arrested growth by high dose of cypermethrin was observed. Histopathological analysis concluded that pesticides at low and high concentrations could be injurious to liver and kidney.

Authors' contributions

Conceived and designed the experiments: MS Sajid \& R Iqbal, Performed the experiments: MS Sajid, Analyzed the data: MS Sajid, M Hussain \& MF Malik, Contributed materials/ analysis/ tools: MS Sajid \& R Iqbal, Wrote the paper: MS Sajid, M Hussain \& SH Shah.

\section{References}

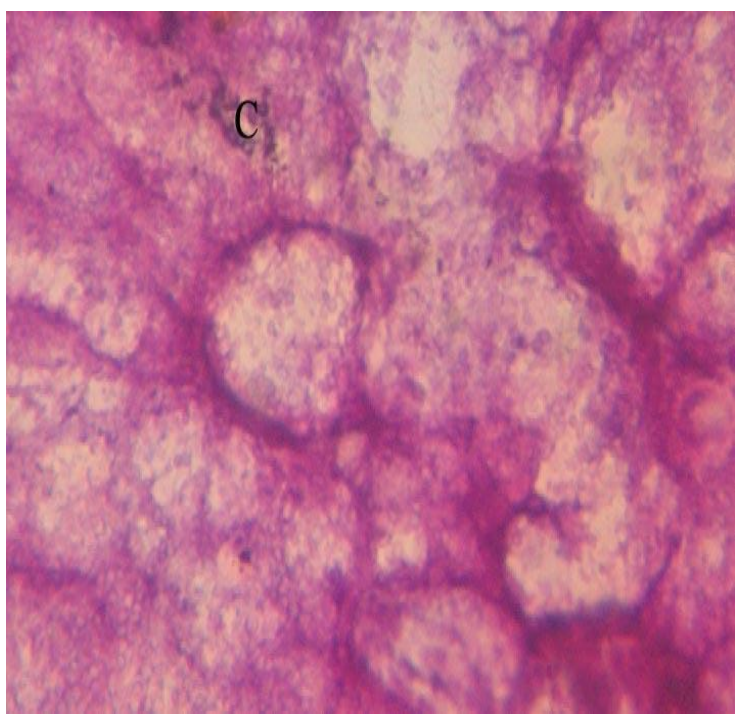

Figure 16. Kidney cross section of low dose group of carbaryl (5 mg/g b.w.) showing Congestion $(\mathrm{C})$. The tubular area and medullary part appear normal at 100x Magnification Power under Light Microscope. No Major Changes Were Seen in this Group

1. Blackburn ST (2007). Chapter 7, Maternal, Fetal \& amp; Neonatal Physiology- A clinical perspective. $3^{\text {rd }}$ Ed. Saunders.

2. Ernest K, Thomas M, Paulose M, Rupa V \& Gnanamuthu C (1997). Delayed Effects of Exposure to Organophosphorus Compounds. Indian J Med Res 101: 81-84.

3. Rull RP, Ritz B \& Shaw GM (2006). Validation of Self-Reported Proximity to Agricultural Crops in a Case-Control Study of Neural Tube Defects. J Expo Sci Environ Epidemiol 16: 147-155.

4. Isenring, R (2010). Pesticides and the loss of biodiversity. How Intensive Pesticide Use Affects Wildlife Population and Species Diversity. Pesticide Action Network, Europe 2542.

5. Krieger R, Zhang X, Williams R \& Dinoff $T$ (2005). Concurrent Passive Dosimetry and Biological Monitoring of Triclopyr and 2, 4-D Exposures of a 
Back-Pack Applicator crew. University of California.

6. Singh AK, Manindra NT, Prakash O \& Singh MP (2012). Current Review of Cypermethrin-Induced Neurotoxicity and Nigrostriatal Dopaminergic Neurodegeneration. Curr Neuropharmacol 10(1): 64-71.

7. Eraslan G, Kanbur M, Silig Y, Karabacak M, Sarlca SZ \& Sahin S (2016). The Acute and Chronic Toxic Effect of Cypermethrin, Propetamphos, and Their Combinations in Rats. $J$ Environ toxicol 31(11): 1415-1429.

8. Li YF, Chen P, Xia HJ, Jing L \& Xu LC (2013). Effects of Cypermethrin on Male Reproductive System in Adult Rats. Biomed Environ Sci 26(3): 201208.

9. Sekhar, PR, Savithri Y, Prakash RY, Kishore S \& Jayantha RK (2010). Cypermethrin and Sodium Fluoride Synergistic Effect on Oxidative Enzymes in Muscle and Kidney of Albino Mice. IJPBS 1.

10. Ullah MS, Ahmad M, Ahmad N, Khan MZ \& Ahmad I (2006). Toxic Effects of Cypermethrin in Female Rabbits. Pak Vet J 26:193-196.

11. Al-Hamdani NMH \& Narasinhachary YH (2011). Endocrine Disruptive Action of Cypermethrin in Male Mice. Toxicol Environ Health Sci 3(2): 69-79.

12. Nagarjuna A \& Doss PJ (2009). Acute oral Toxicity and Histopathological Studies of Cypermethrin in Rats, Indian J Anim Res 43: 235-240.

13. Todd NE \& Van LMV (2002). Effects of Sevin (carbaryl insecticide) on Early Life Stages of Zebrafish (Daniorerio). Ecotoxicol Environ Saf 53: 267-272.

14. Lauan M \& Ocampo P (2012). Lowdose effects of Carbaryl, Chlorpyrifos and Imidacloprid on the Gonad and Plasma Testosterone Level of Male Juvenile and Adult Nile Tilapia
(Oreochromis niloticus). Asia Life Sciences 1: 239-250.

15. Sahai V (2013). Carbaryl Induced Histological Changes in the Liver of Albino Mice. $J$ of Entomol and Zool Studies 1(4): 145-149.

16. Ghazala M, Mahboob S, Al-Ghanim KA, Sultana S, Alkahem, Al-Balawi, Sultana T, Al-Misned F \& Ahmed Z (2015). A Study on Acute Toxicity of Triazophos, Profenofos, Carbofuran and Carbaryl Pesticides on Cirrhinus mrigala. Pak J Zool 47(2): 461-466.

17. Rani A, Sahai A \& Srivastava AK (2007). Carbaryl Induced Histopathological Changes in the Testis of Albino Rats. Journal of the Anatomical Society of India 56: 4-6.

18. Hamid S, Sharm S \& Razdan, S (2012). Carbaryl, a Pesticide Causes "Reproductive Toxicity" in Albino Rats. J Clin Exp Pathol 2: 126.

19. Hau J \& Van HG, (2003). Handbook of Laboratory Animal Science, Vol 1.

20. Jali PK, Donoghue M, Gadiwan M. (2015). A Rapid Manual Processing Technique for Resource-Limited Small Laboratories. $J$ of Oral and Maxillofacial Pathol 19(3): 306.

21. Murray FJ, Staples RE \& Schwetz BA. (1979). Teratogenic Potential of Carbaryl Given to Rabbits and Mice by Gavage or by Dietary Inclusion. Toxicol Appl Pharmacol 51: 81-89.

22. Dikshith TS, Gupta PK, Gaur JS, Datta KK \& Mathur AK (1976). Ninety Day Toxicity of Carbaryl in Male Rats. Environ Res 12: 161-170.

23. Weil CS, Woodside MD, Carpenter CP \& Smyth HF (1972). Current Status of Tests of Carbaryl for Reproductive and Teratogenic Effect. Toxicol Appl Pharmacol 21: 390-404.

24. Dougherty WJ, Golberg L \& Coulston F (1971). The Effect of Carbaryl on Reproduction in the Monkey (Macacca 
mulatta).Toxicol Appl Pharmacol 19: 365.

25. Benson WH \& Dorough W (1984). Comparative Ester Hydrolysis of Carbaryl and Ethiofencarb in Fourth Mammalian Species. Pestic Biochem Physiol 21: 199-206.

26. Vashakidze VI (1965). Some Questions of the Harmful Action of Sevin on the Reproductive Functions of Experimental animals. Soobshch Akad Nauk Bruz SSR 39: 471-474.

27. Robens JF (1969). Teratologic Studies of carbaryl, Diazinon, Disulfiram, and Thiram in Small Laboratory Animals. Toxicol Appl Pharmacol 15: 152-163.

28. Mathur A \& Bhatnagar P (1991). A Teratogenic Study of Carbaryl in Swiss Albino Mice. Food and Chem Toxicol 29: 629-632.

29. Lechner DW \& Abdel RMS (1984). A Teratology study of carbaryl and malathion mixtures in rat. $J$ Toxicol Environ Health 14(2-3): 267-78.

30. Khurshid A (2003). Cypermethrin, a Pyrethroid Insecticide Induces Teratological and Biochemical Changes in Young Chick Embryos. Pak J Biol Sci 6(19): 1698-1705.

31. Ismail A (2012). Embryo toxicity and Teratogenic Potential of Cypermethrin and Diazinon Insecticides on Japanese Quail Chick-Embryos (Coturnix Japonica). J Plant Prot and Path Mansoura Univ 3(12): 1269-1286.

32. Farag AT, Goda NF, Mansee AH \& Shaaban NA (2006). Effects of Permethrin Given Before Mating on the Behavior of F1-Generation in Mice. Neurotoxicol 27(3): 421-428.

33. Raees K, Asmatullah \& Ahmad KR (2010). Pregnancy and Fetal Correlations of Cypermethrin in Mice (Mus musculus). Biologia 56(1\&2): 3954.
34. Murkunde YV, Sathya TN, Subashini N \& Murthy PB (2012). Transplacental Genotoxicity Evaluation of Cypermethrin Using Alkaline Comet Assay. Hum Exp Toxicol 31(2): 185-92.

35. Assayed ME, Khalaf AA \& Salem HA (2010). Protective effects of garlic extract and vitamin $\mathrm{C}$ against in vivo cypermethrin-induced teratogenic effects in rat offspring. Food. Chem Toxicol 48(11): 3153-3158.

36. Rustamov YM \& Abbasov TG (1994). Gonadotoxic Action of Cypermethrin in Rats Given Multiple Doses. Prob. Vet. Sanit 94: 88-95.

37. Anwar K (2003). Cypermethrin, a Pyrethroid Insecticide Induces Teratological and Biochemical Changes in Young Chick Embryos. Pak J Biol Sci 6: 1698-1705.

38. The European Agency for the Evaluation of Medicinal Products (EMEA) (2002). Veterinary Committee for Veterinary Medicinal Products: Cypermethrin. Summary Report 1. EMEA/MRL/403/98.

39. Manna S, Bhattacharyya D, Mandal TK \& Das S (2004). Repeated dose toxicity of alpha-cypermethrin in rats. $J$ Vet Sci 5(3): 241-245.

40. Iyaniwura TT \& Okonkwo CA (2004). The Acute Intraperitoneal Toxicity of Cypermethrin. Vet. Hum. Toxicol 46 (2): 91-92.

41. Grewal KK, Sandhu GS, Ranjit K, Brar RS \& Sandh HS (2010). Toxic Impacts of Cypermethrin on Behavior and Histology of Certain Tissues of Albino Rats, Toxicol Inter 17: 94-98.

42. Ton LS, Prezbirowska D, Latuszynska J \& Tokarska RM (2001). Histological and Ultrastructural Studies of Rats Exposed to Carbaryl. Ann Agric Environ Med 8: 137-44. 